Semina $\square \quad \mathrm{Nr} 15$

Scientiarum 2016

s. $107-123$

DOI: http://dx.doi.org/10.15633/ss.1771

dr Katarzyna Eliasz

Marek Jakubiec

\title{
The Vienna Circle and the Uppsala School as philosophical inspirations for the Scandinavian Legal Realism
}

Since the beginning of the $20^{\text {th }}$ century the Swedish philosophical scene was strongly influenced by the Uppsala School in philosophy, a current known for its hostility towards all forms of widely understood metaphysics. Rejection of metaphysics led the Uppsala philosophers to believe that the only reality we can meaningfully speak of is a spatio-temporal realm, to noncognitivism in terms of values and to the conviction that the role of philosophy is limited to clarification of concepts through logical analysis. Such a brief description reveals a similarity between the Uppsala School and the Vienna Circle.

The representatives of the Vienna neopositivistic movement not merely formulated the verificationist criterion of meaningfulness, but also believed any form of unverifiable sentences (especially metaphysical stetaments and concepts) is to be removed from our scientific and philosophical language. This position led them to the radical form of empiricism, extremely controversial and widely criticized, though inspiring for contemporary philosophers. The emotivist propositions formulated by philosophers inspired by Vienneses were a kind of implication of the acceptance of the noncognitivist approach in metaethics. Eventually, the only purpose of philosophical investigations was considered to be the analysis of the language 
of science; the proposals indicating its traditional tasks, like looking for the truth, were rated as illegitimate.

A sketchy analysis reveals a prima facie resemblance between the Uppsala School and the Vienna Circle. Both currents presented hostility towards metaphysics and claimed that reality should be understood as a spatio-temporal order and asserted to non-cognitivism in terms of value-judgments. ${ }^{1}$ However, it should be remembered that the philosophical program of the Uppsala School was formulated during the first decade of the $20^{\text {th }}$ century, twenty years before Die wissenschaftliche Weltauffassung der Wiener Kreis (published in 1929). The main assumptions of the two mentioned schools (despite significant differences visible in a more thorough analysis), were coherent enough to provide a philosophical basis for the development of a new current in jurisprudence that is Scandinavian Legal Realism.

In our article we focus on two main theses of both schools, which influenced the Scandinavian Legal Realism to the largest extent. In the first section we describe and compare the anti-metaphysical assumptions of the Uppsala School (we focus on philosophical investigations of the founder and the main representative of the school, Axel Hägerström) and the Vienna Circle: we point out obvious parallels but also indicate a major difference, namely a basis for the rejection of metaphysics. Having presented ontological frameworks provided by both schools, we move on to metaethical noncognitivism. In the second section we indicate how these philosophical investigations affected the theory of Alf Ross (1899-1979), probably the most recognized philosopher among the Scandinavian legal realists. In order to reveal the impact that the Vienna Circle and the Uppsala School had on his investigations, we will focus on his theory of legal validity and legal concepts. The reason for considering Ross is twofold. Firstly, he was the only philosopher among Scandinavian realists, who developed a theory, which was an attempt to accommodate both Uppsala philosophy and the logical empiricism of the

1 R. T. Sandin, The founding of the Uppsala School, "Journal of the History of Ideas" 23 (1962) 4, p. 496. 
Vienna Circle (while other Scandinavian realists relied mainly on philosophy of the Uppsala School). Secondly, Ross is considered to be the most prominent representative of the realist movement, probably because his theory is the most sophisticated and thorough vision of legal phenomena, while being a significant alternative for other movements in legal philosophy such as natural law theory, legal positivism, the historical school, but also other realist movements, especially American Legal Realism.

In the following paragraph we analyze the anti-metaphysical assumptions presented by both aforementioned currents. The hostility towards all forms of widely understood metaphysics was certainly 'inherited' by all Scandinavian realists, and therefore requires a closer presentation.

\section{The Uppsala School and the Vienna Circle: rejection of metaphysics}

Philosophical aversion to the metaphysical speculations is nihil novi under the philosophical sole. One of the most famous quotes expressing the striving for the elimination of not empirical (and mathematical) reasonings can be found in Hume's Enquiries concerning the human understanding and concerning the principles of morals:

When we run over libraries, persuaded of these principles, what havoc must we make? If we take in our hand any volume of divinity or school metaphysics, for instance, let us ask, „Does it contain any abstract reasoning concerning quantity or number?” No. „Does it contain any experimental reasoning concerning matter of fact and existence?" No. Commit it then to the flames, for it can contain nothing but sophistry and illusion. ${ }^{2}$

Therefore, the representatives of the Uppsala School and the Vienna Circle certainly did not propose an entirely new idea of

2 D. Hume, An enquiry concerning human understanding, Oxford 1902, p. 165. 
anti-metaphysicism; they have rather formulated new arguments against the presence of metaphysics in the catalogue of meaningful philosophical disciplines.

Anti-metaphysicism of the Uppsala School arose as a result of the rejection of subjectivism. Such an approach was developed by C.J. Boström (1797-1866), under the influence of Berkeley's esse est percipi principle. Boström maintained that the objects are merely correlates of consciousness. ${ }^{3}$ Boströmianism with its epistemological subjectivism provided an important background for the development of the Uppsala School. Axel Hägerström (1868-1939) and Adolf Phalen (1884-1931), two prominent Swedish philosophers, rejected Boströmian subjectivism. Axel Hägerström (who received the greatest recognition among all Uppsala philosophers), in Das Prinzip der Wissenschaft (1908) formulated so-called 'thesis of reality', which provided the name for the new current, the Scandinavian Legal Realism. ${ }^{4}$ Hägerström pointed out that subjectivism struggles with the problematic issue of concerning possibility of perceiving 'something' (an object) as independent from a subject. In other words, the question is: how can the conscious subject recognize those aspects of the reality, which do not belong to the consciousness? Young Hägerström aimed at resolving the puzzle of subjectivism basing on Kantianism, seeking to answer the question of how is it that the mind recognizes an object as 'something' separate from the mind. According to Kant, categories such as time or space, which allow for the separation of objects in experience, are merely certain forms of consciousness. ${ }^{5}$ Hägerström realized, that as a result of Kant's 'Copernican Revolution', the object of consciousness is created partly by the cognizing subject. Hägerström, dissatisfied with the Kantian solution, proposed a 'counterrevolution' claiming that ultimately it is the reality that is given in cognition, and not merely the consciousness. As we may now see, metaphysics in the modern

\footnotetext{
R. T. Sandin, The founding of the Uppsala School, op. cit., pp. 489-499.

P. Mindus, A real mind. The life and work of Axel Hägerström, Dordrecht 2009, p. 48.

5 R. T. Sandin, The founding of the Uppsala School, op. cit., pp. 503-504.
} 
philosophy - according to Hägerström - stems from the false theory of knowledge. However, if one rejects subjectivism with its conviction that the mind cannot apprehend directly anything but itself, knowledge will be possible without reference to metaphysics. ${ }^{6}$ Having that in mind, Hägerström claimed that acts and objects of consciousness are two distinct phenomena; what is truly given in cognition is an independent reality; in other words, 'realism' mentioned in the 'thesis of reality' implied that objects have ontological autonomy. As we mentioned in the introductory remarks, Uppsala philosophers adhered to a narrow vision of metaphysics. Anything located outside of a spatio-temporal realm had to be rejected merely speculative. It is, however, important to underline, that according to Hägerström also mental states are 'real', as they belong to the world of experience "in so far as [...] it is placed in time and its reality is hence only time-dependent." Mental states do belong to the world of time and space, however indirectly. This assumption - as we indicate below - will be of importance for the Scandinavian legal realists.

The rejection of metaphysics by Hägerström (and other representatives of the Uppsala School) found its clearest formulation in Hägerström's motto: Praeterea censeo metaphysicam esse delendam ('Moreover, I propose that metaphysics shall be destroyed'), a paraphrase of the famous words of Cato the Elder. This hostility towards metaphysics reflected in moral philosophy. Hägerström adhered to a noncognitivist, emotivist theory of values twenty years before the formulation of the program of the Vienna Circle. Such a novelty in a conservative Swedish society influenced by Boströmian idealism met with incomprehension, and attracted criticism towards Hägerström whose theory was labeled as 'axiological nihilism'. ${ }^{8}$ Hägerström presented his metaethical views to the public during his infamous lecture entitled On the truth of moral propositions delivered in March 1911. Swedish philosopher outraged his listeners (along with

6 R. T. Sandin, The founding of the Uppsala School, op. cit., p. 508.

A. Hägerström, Das Prinzip der Wissenschaft..., op. cit., s. 76.

$8 \quad$ P. Mindus, A real mind..., op. cit., p. 81. 
the chancellor of the Uppsala University Henrik Schück ${ }^{9}$ ) claiming that ultimately value judgments cannot be considered to be true or false. Let's consider his conclusion in more detail. For Hägerström the consciousness of value or consciousness of duty is an expression of emotional experience. However if we claim that propositions of value are of emotional kind, be have to agree - Hägerström claimed that they cannot be considered as judgments.

Unlike the sensations, what we experience in the emotions lacks all spatial definiteness. It cannot be introduced therefore into a large whole as part of reality. Hence emotion as such is not an observation, not a consciousness of reality of the object, but the emotive quality is 'introjected' into the 'inner ego'. It is always an ego which is glad, sorry etc. Precisely because the emotion lacks all spatial definiteness it is ascribed to the ego as a spiritual world different from the spatial. [...] The emotion as experience is conceived to be associated with the psycho-physical organism and accordingly with reality. But thus the emotion is always only real as experience. [...] Words such as 'pleasure' and the like therefore always denote something merely subjective, something which lacks all reference to physical reality - unlike observation which indeed is conceived as subjective too (experience, consciousness), but is also a consciousness of something as being real. If these statements are true, emotive consciousness can never take the form of a judgment in such a way that the experienced emotive quality in the judgment can be determined as a part of reality. ${ }^{10}$

If moral propositions are not judgments, they cannot be considered as true or false in terms of logic. Obviously the above quotation can trigger objections, but if one takes Hägerström's considerations for granted, one have to agree to his conclusions. ${ }^{11}$ If however one

$9 \quad$ P. Mindus, A real mind..., op. cit., p. 77.

10 A. Hägerström, as cited in: A. Ross, On the logical nature of propositions of value, "Theoria" (1945) 11 (3), p. 187.

11 Alf Ross, despite generally accepting Hägerström's investigations, claims that his theory of feelings is not a conclusive argument for the assertion of the non-logical character of propositions of value: "Hägerström's theory has the character of an un- 
is dissatisfied with Hägerström's comments on emotive consciousness, it is possible to find other justifications for his noncognitivism. According to a less sophisticated argument such entities as moral values have no counterparts in all encompassing spatio-temporal reality. This ontological claim leads us to epistemological and semantic arguments. According to epistemological argument, it is impossible to gain knowledge about values, as such knowledge cannot be subjected to empirical verification (because such values are 'alien' to the accepted vision of reality). According to the semantic argument propositions of value lack reference, therefore we cannot use them as elements of meaningful description of reality (one cannot find any designate of 'good' in all-encompassing spatio-temporal framework). The theory developed by logical positivists may seem to be quite alike.

Much ink has been spilled over the philosophical output of the Vienna Circle philosophers, therefore we will merely note the most relevant aspects of their refutation of metaphysical statements. Their point of departure is the idea of verification, according to which every meaningful statement is reducible to Protokollsätze (protocol sentences) - statements which describe direct experience or perception. According to the neopostivistic epistemology, these statements are held to be the ground for meaningful sentences, theories and, in general, parts of knowledge. Theories that are not empirically based, cannot be reduced to such sentences and, consequently, it is not possible to verify them in the proposed, empirical way. In other words, the significance of a certain statement has to be conceived of as having a potential to receive direct or indirect experiential support. ${ }^{12}$ In connection with the verificationist criterion of demarca-

warranted generalization. He bases his analysis on certain typical cases (pleasure), in which the emotion is clearly regarded as belonging to the ego as something subjective. He bases his general theory on this and than in virtue of it brands illusory the cases in which emotive qualities, at any rate apparently, are regarded as belonging to the surrounding world. I think that it is actually impossible to maintain, as a psychological description, Hägerström'a assertion that emotion has never any reference to space." A. Ross, On the logical nature of propositions of value, op. cit., p. 189.

12 T. Uebel, Vienna Circle, [in:] The stanford encyclopedia of philosophy, ed. E. N. Zalta, http://plato.stanford.edu/entries/vienna-circle/ (29.02.2016). 
tion, according to which merely verifialble sentences are to be evaluated as meaningful, all unempirical theories and concepts transpire as devoid of any meaning and, therefore, are useless.

As one can see, the elimination of metaphysics in the publications of the Vienna Circle members was of different character (in our opinion is was a result of more philosophically sophisticated reasononigs) than in the Uppsala school, possibly due to the formalistic character of their philosophy and concentration on mathematized natural sciences, especially on physics (many of them were educated in science, not merely in the philosophy).

The problems of ethics and axiology did not play an important role in the philosophical investigations of the Vienneses. ${ }^{13}$ The noncognitivist approach did not appear in their important philosophical publications. This "gap" was filled by Alfred Jules Ayer, British philosopher, inspired by the Vienna Circle members. In his famous book, Language, truth and logic, ${ }^{14}$ which was a kind of neopositivistic international manifesto, Ayer proposed an emotivist theory, which became one of the most important metaethical theories in the 20th century. His argumentation is partially similar to Hägerström's ideas, but one can note also relevant differences.

The principle of verification is of great importance in his reasoning concerning the significance of moral utterances. Due to the fact that the statements expressing moral attitudes or norms are prescriptive (not descriptive), it is impossible to verify them in the empirical way. In Ayer's opinion, these statements are expressions of the speaker's feelings. In this context, his position is similar to the Hägerström's (Ayer also denied such expressions were assertions). It may be simply noticed in his $L T L$. As he writes in the part entitled Critique of ethics and theology:

13 See, for instance: Ethik und Werturteilsproblematik im Wiener Kreis', [in:] Von Bolzano zu Wittgenstein. Zur Tradition der österreichischen Philosophie, Hrsg. J. C. Nyiri Wien 1986, pp. 162-172 (Schriftenreihe der Wittgenstein-Gesellschaft, 12/2).

14 A. J. Ayer, Language, truth and logic, London 1936. 
[...] statements of value are genuine synthetic propositions, but that they cannot with any show of justice be represented as hypotheses, which are used to predict the course of our sensations; and, accordingly, that the existence of ethics and aesthetics as branches of speculative knowledge presents as insuperable objection to our radical empiricist thesis. In face of this objection, it is our business to give an account of "judgements of value", which is both satisfactory in itself and consistent with our general empiricist principles. We shall set ourselves to show that in so far as statements of value are significant, they are ordinary 'scientific' statements and that in so far as they are not scientific, they are not in the lieral sense significant, but are simply expressions of emotion which can be neither true nor false. ${ }^{15}$

\section{Alf Ross' naturalized jurisprudence}

While all Scandinavian legal realists espoused philosophy of the Uppsala school, Alf Ross combined both: the teachings of Hägerström and the logical positivism in one coherent legal theory. Hägerström's contribution to Ross' legal philosophy is particularly apparent in two of his books: Kritik der sogennannten praktischen Erkenntnis (1933) and Towards a realistic jurisprudence (1946). However, in his best-known work On law and justice (1953) Ross distanced himself from the teachings of Hägerström and turned to the philosophy of the Vienna Circle. This change was not radical for two reasons. Firstly, what will become clear below, Ross did not consequently develop basic methodological requirements of Carnap or Neurath. Secondly, Ross' theory of legal validity and legal concepts drew inspirations from the basic naturalistic assumptions of both schools, which can be joined together without much controversy and without exposing his theory to incoherence. Jens Evald in his biography of Ross claims that: "His [Ross'] aim was not to disown Hägerström but to present the Uppsala School as a philosophical school

15 A. J. Ayer, Language, truth and logic, op. cit., p. 104. 
parallel to logical positivism." ${ }^{16}$ Ross encountered logical empiricism of the Vienna Circle in 1934 when he became acquainted with Neurath who arrived to Copenhagen with lectures. Ross, impressed by the program of logical positivists, in a letter to Gunnar Myrdal wrote that: "Influenced by Carnap and Neurath, representatives of the unitary science of Viennese philosophy, I have been inspired to continue certain epistemological problems, which have already been identified in Kritik [...]."17 The two inspirations: the Uppsala School and the Vienna Circle constitute the greatest contribution for Ross' legal theory.

Scandinavian realism was supposed to be an alternative to the legal theories that developed idealistic or partly idealistic understanding of validity. According to Ross this idealism is best visible in natural-law theories and in Hans Kelsen's normativism, however it is present 'in disguise' also in legal positivism of Austin or Bergbohm. ${ }^{18}$ Legal validity is problematic, as legal norms are obviously social phenomena, but at the same time they are considered to be a priori valid. Ross formulated this problem in the following manner:

[...] it may be said that law is conceived at the same time as an observable phenomenon in the world of facts, and as a binding norm in the world of morals or values, at the same time as physical and metaphysical, as empirical and a priori, as real and ideal, as something that exists and something that is valid, as a phenomenon and as a proposition. ${ }^{19}$

Ross, who inherited Hägerström's hostility towards metaphysics, saw the need to interpret the law and its validity only in terms of physical reality. Validity and reality are not two irreconcilable entities, but two aspects of one phenomenon. Let's once again consider, that inspired by Hägerström, Ross claimed that individual psycho-

16 J. Evald, Alf Ross. A life, Copenhagen 2014, p. 220.

17 J. Evald, Alf Ross. A life, op. cit., p. 217.

18 See. A. Ross, Towards a realistic jurisprudence, Copenhagen 1946, p. $53 \mathrm{ff}$.

19 A. Ross, Towards a realistic jurisprudence, op. cit., p. 11. 
logical phenomena fall into such spatio-temporal reality. Propositions about the validity of law refer to a certain set of social and psychological facts. These facts are decisions of the judges. ${ }^{20}$ According to Ross a doctrinal assertion " $\mathrm{A}=\mathrm{D}$ is valid law, is a prediction to the effect that $\mathrm{D}$ under certain conditions will be taken as the basis in future, legal disputes." ${ }^{21}$ Lets now analyze elements of this definition. Ross claimed, that scientific legal doctrine needs to be norm-descriptive, not norm-expressive:

Since the doctrinal study is concerned with norms, it can be called normative. But the term must not be misunderstood. [...] Cognitive propositions can naturally not be made up o norms (directives). They have to consist of assertions - assertions concerning norms, which again means assertions to the effect that certain norms are of the nature of "valid law". The normative character of the doctrinal study of law signifies, therefore, that it is a doctrine concerning norms, and not of norms. It does not aim "setting up" or expressing norms, but at establishing their character of "valid law". 22

Assertions about valid law are predictions to the effect, that if an action is brought before the court, the directive for the judge will form a part of reasoning underlying the judgment. Here we need to move on to the most important contribution of the Vienna Circle to Ross' theory of validity. Such doctrinal assertions are considered meaningful only if they undergo the procedure of empirical verification ("a proposition about valid law is to be verified by fulfilling the prescribed conditions and observing the decision." ${ }^{23}$ ) What makes that predictions possible, or - in other words - how can a le-

20 Ross considered the decisions of judges to be the indications for the content of valid law, because judges, unlike layman, have coherent beliefs as to what is the law. Moreover the effectiveness of law - which for Ross is a condition for its validity - can be best tested before the courts.

21 A. Ross, On law and justice, Berkeley 1959, p. 75.

22 A. Ross, On law and justice, op. cit., p.19.

23 A. Ross, On law and justice, op. cit., p. 41. 
gal scholar predict whether or not a judge will use a certain rule as a basis for his future decision? ${ }^{24}$

If [...] prediction is possible, it must be because the mental process by which the judge decides to base his decision on one rule rather than another is not a capricious and arbitrary matter, varying from one judge to another, but a process determined by attitudes and concepts, a common normative ideology, present and active in the minds of judges when they act in their capacity as judges. It is true that we cannot observe directly what takes place in the mind of the judge, but it is possible to construct hypotheses concerning it, and their value can be tested simply by observing whether predictions based on them have come true. ${ }^{25}$

The shared normative ideology, which is shaped by the broad catalog of the sources of law, enables the scholar to form predictions. These sources are the acts of legislature, custom, precedent and 'tradition of culture'. ${ }^{26}$ Some of these sources (like bills) provide stronger basis for predictions (the scholar considers them to have high probability of being applied by the judge) while others provide weaker basis (like a single precedent). From this it follows that predictions are a matter of degree. Moreover, according to Ross rules themselves have a gradable character. ${ }^{27}$

Having briefly outlined Ross' theory of legal validity, let us now consider his adherence to logical positivism. In On law and justice, Ross explicitly referred to principle of verification as to an important basis for his predictive theory:

It is a principle of modern empirical science that a proposition about reality [...] must imply that by following a certain mode of procedure, under certain conditions certain direct experiences will result. The prop-

${ }^{24}$ It is worth noting, that Ross claimed that predictions are not directed to the outcome of hypothetical future case, but are only to indicate which rule will be used as a basis for the decision.

25 A. Ross, On law and justice, op. cit., p. 75.

26 A. Ross, On law and justice, op. cit., pp. 75-78.

27 A. Ross, On law and justice, op. cit., p. 45. 
osition, for example, "this is chalk" implies that if I place the object under a microscope certain structural qualities shall appear; if I pour acid over it, certain chemical reactions will result; if I rub it on a blackboard a line will show, and so on. This mode of procedure is called the procedure of verification and the sum of verifiable implications is said to constitute the "real content" of the proposition. [...] The interpretation of the doctrinal study of law presented in this book rests upon the postulate that the principle of verification must apply also to this field of cognition - the doctrinal study of law must be recognized as empirical social science. ${ }^{28}$

In our opinion, his understanding of verification was however different from the one adopted by Carnap or Neurath. Ross' understanding of verification was significantly wider and simpler, as by 'verification' he meant just occurrence of testable consequence (for neopositivists verification was rather, generally speaking, a less or more formalized procedure of checking the epistemic value of certain sentences). Moreover, procedure of verification has been traditionally applied to non-probabilistic scientific propositions, while Ross' doctrinal propositions are probabilistic. Moreover, Ross never proposed to reduce assertions about legal validity to protocol sentences, what would be required in order to consequently apply Carnap's assumptions. Due to these factors discussion concerning the adequacy of verificationist approach does not affect Ross' philosophy. Latter refutation of verificationism, the acceptance of conformation and probabilistic approach in the philosophy of science seems to be irrelevant from the perspective of Scandinavian realist movement.

The second issue which is appealing in the light of antimetaphysical attitude of the Vienna and Uppsala philosophers is the status of legal concepts. Taking into account aforementioned aspects of Ross' philosophy, the character of legal concepts may be analyzed from the new, naturalistic perspective. His relevant paper in this context is

28 A. Ross, On law and justice, op. cit., pp. 39-40. 
Tû-Tû, published in Harvard Law Review in 1957. ${ }^{29}$ The argumentation proposed by Danish philosopher may be interpreted as double track in the certain sense: on the one hand is based on his pragmatic approach, on the second on the anti-metaphysical position.

The first issue is of a great importance from rather practical than theoretical view, though it is also philosophically complex. ${ }^{30}$ At the beginning of the paper, Ross describes the customs of an imaginary tribe, Noit-cif, which lived at Noisuli islands. He pays special attention to the problem of ritual purification. The word which is crucial in this procedure is the eponymous $t \hat{u}$-t $\hat{u}$. Members of the society use it to indicate specific states of affairs, linked to the violation of social norms. ${ }^{31}$ In such a situation, the member who infringed the norm becomes $t \hat{u}$-t $\hat{u}$ and, consequently, his position in the hierarchy rapidly goes down.

Further Ross explains the meaning of $t \hat{u}$-t $\hat{u}$ and ascertains the word has no semantic reference. ${ }^{32}$ It does not imply, however, the language of our tribe is devoid of meaning or ununderstandable. On the contrary, the statements including this utterance, are clear for the interlocutors. Moreover, the word which does not have real designates is an important element of the structure of tribe's language. As Ross observes, assertion ' $x$ is $t \hat{u}$-t $\hat{u}$ ' occurs in definite semantic connection with a complex situation of which two parts can be distinguished:

(i) The state of affairs in which $x$ has either eaten of the chief's food or has killed a totem animal or has encountered his mother-in-law, etc. This state of affairs will hereinafter be referred to as affairs . $_{1}$. (ii) The state of affairs in which the valid norm which requires ceremonial purification is applicable to $\mathbf{x}$, more precisely stated as the state of affairs in which if $x$ does not submit himself to the ceremony he will in all probability be exposed to a given reaction on the

29 The text was published earlier in Danish in Festskrift til dr. juris Henry Ussing, 5. maj 1951, red. O. Borum, K. Ilium, Kobenhavn, 1951.

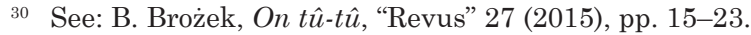

31 Ross describes inter alia these situations: "If a person $\mathrm{x}$ has killed a totem animal, $\mathrm{x}$ is tû-tû; If a person $\mathrm{x}$ has eaten the food prepared for the chief, $\mathrm{x}$ is tû-tû".

32 A. Ross, Tû-Tû, „Harvard Law Review” 70 (1957) 5, p. 814. 
part of the community. This state of affairs will hereinafter be referred to as affairs $_{2} \cdot{ }^{33}$

Then, through the analysis of some inferences, he demonstrates that $t \hat{u}-t \hat{u}$ is devoid of any meaning. In our opinion, his thesis is based not merely on such purely linguistic analysis, but also on the anti-metaphysical attitude, inspired by both the Vienna Circle and the Uppsala School, which we have already mentioned.

We should note that the reference of the legal concepts can be analyzed from at least two perspectives. The first, realistic, presupposes that the subject of our investigations is a set of "legal facts". They may be interpreted as sociological, psychological or even neuroscientific, but, generally, are directly linked to the human behavior. The second, which can be called "metaphysical" (this term is obviously controversial), is based on the analysis of abstract legal concepts, to which a kind of 'reality' is ascribed. ${ }^{34}$ Such position is not acceptable for Ross and the rest of the Scandinavian legal scholars. As Hart remarked, Ross maintained that if a statement is not an expression of facts (which can be verified in the empirical way) or feelings it is a metaphysical statement. ${ }^{35}$ If a statement is metaphysical it is, according to the neopositivists, senseless. The same criterion is to be applied to the analysis of concepts; then, if a concept is not based on a empirically verifiable factors (or does not express the facts), it is a metaphysical concept.

When we consider the concept of "obligation" and utterances it constitutes one can observe it is impossible - generally speaking to empirically verify the meaning of such sentence. On the other hand, as it was previously stated, Ross' understanding of the principle of verification was simplified and, in our opinion, not fully correct. Therefore it would be interesting to consider whether the more adequate acceptance of the Vienna Circle proposals (certainly in the

33 A. Ross, Tû-Tû, op. cit., p. 814.

34 M. Jakubiec, Tû-Tû Alfa Rossa a tezy skandynawskiego realizmu prawnego, [in:] Naturalizm prawniczy. Stanowiska, red. J. Stelmach i in., Warszawa 2015, pp. 205-206.

${ }^{35}$ H. L. A. Hart, Scandinavian realism, "The Cambridge Law Journal" 17 (1959) 2 , p. 236. 
analogical way) is possible and if can be useful for legal philosophers. However, such an analysis is to be a subject of an other research.

\section{Summary}

\section{The Vienna Circle and the Uppsala School as philosophical inspirations for the Scandinavian Legal Realism}

The Uppsala School in philosophy and the Vienna Circle are prima facie similar currents in contemporary philosophy. Both reject metaphysics, claim that reality is a spatio-temporal realm and adhere to noncognitivism in terms of values. However, justifications of these assumptions are quite different. In the following article we reconstruct main theses of both mentioned currents and then we indicate their impact on one of the major jurisprudential movements, namely Scandinavian Legal Realism. We focus on Alf Ross' legal philosophy, as it was an attempt to accommodate both: the philosophy of the Uppsala School and of the Vienna Circle (while other Scandinavian realists referred exclusively to Uppsala philosophy). We trace those two sources of inspiration in Ross' theory of legal validity and of legal concepts.

Keywords Vienna Circle, Uppsala School, legal realism, neopositivism

\section{Bibliografia}

Ayer A. J., Language, truth and logic, London 1936.

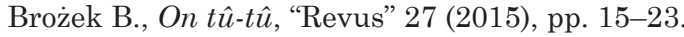

Evald J., Alf Ross. A life, Copenhagen 2014.

Hägerström A., Das Prinzip der Wissenschaft. Eine logisch-erkenntnistheoretische Untersuchung, Uppsala 1908.

Hart H. L. A., Scandinavian realism, "The Cambridge Law Journal" 17 (1959) 2 , pp. 233-240.

Hume D., Enquiries concerning the human understanding and concerning the principles of morals, Oxford 1902.

Jakubiec M., Tû-Tû Alfa Rossa a tezy skandynawskiego realizmu prawnego [in:] Naturalizm prawniczy. Stanowiska, red. J. Stelmach i in., Warszawa 2015, pp. 201-220. 
Mindus P., A real mind. The life and work of Axel Hägerström, Dordrecht 2009.

Ross A., On law and justice, Berkeley 1959.

Ross A., On the logical nature of propositions of value, "Theoria" (1945) 11 (3), pp. 172-210.

Ross A., Towards a realistic jurisprudence, Copenhagen 1946.

Sandin R. T., The founding of the Uppsala School, "Journal of the History of Ideas" 23 (1962) 4, pp. 496-512.

Uebel T., Vienna Circle [in:] The stanford encyclopedia of philosophy, ed. E. N. Zalta, 2014http://plato.stanford.edu/entries/vienna-circle/; access: 29.02.2016. 